\title{
COVID-19 と腎臓病
}

土井洋平*, 猪阪善隆

\section{COVID-19 and kidney disease}

\author{
Yohei DOI, Yoshitaka ISAKA
}

Key words: COVID-19, chronic kidney disease, acute kidney injury, RAS inhibitor

\section{1. はじめに}

Coronavirus disease 2019 (COVID-19)は severe acute respiratory syndrome coronavirus 2 (SARS-CoV-2) に よって肺炎などが引き起こされる急性呼吸器疾患で あるが, 同時に腎, 心血管, 神経, 消化管, 内分泌, 凝固線溶系などの様々な肺外病変を呈することが知 られている。臨床的に重要な COVID-19 と腎臓病と の接点は, 慢性腎臓病 (chronic kidney disease: CKD) が COVID-19 の重症化リスクであることと COVID-19 に腎障害を合併することの 2 点である. また腎蔵病治療の key drug であるレニン・アンジオ テンシン系阻害薬（RAS 阻害薬）とCOVID-19の関 係について最近の知見を紹介する。

\section{COVID-19 重症化リスクとしての CKD}

CKD は COVID-19 関連死亡リスクであることが 2020 年 7 月 Nature 誌に報告された ${ }^{1)}$.このコホート 研究 (OpenSAFELY) は英国の約 40\%にあたる 1,700 万人以上のプライマリーケア診療データと約 11,000 の COVID-19 関連死亡デー夕を結びつけたもので, 推定糸球体濾過量 (estimated glomerular filtration rate: eGFR） $60 \mathrm{~mL} / \mathrm{min} / 1.73 \mathrm{~m}^{2}$ 以上と比較し, eGFR 30$60 \mathrm{~mL} / \mathrm{min} / 1.73 \mathrm{~m}^{2}$ で調整後ハザード比（adjusted hazard ratio：aHR 1.33 [95\%信頼区間 1.28 1.40]),

*責任者連絡先：

大阪大学大学院医学系研究科腎臓内科学

干 565-0871 大阪府吹田市山田丘 2-2

Tel: 06-6879-3857, Fax: 06-6879-3230

E-mail: ydoi@kid.med.osaka-u.ac.jp
eGFR $<30 \mathrm{~mL} / \mathrm{min} / 1.73 \mathrm{~m}^{2}$ で aHR 2.52（95\%信頼区 間 2.33 2.72), 透析療法を必要とする患者において は aHR $3.69 （ 95 \%$ 信頼区間 3.09〜4.39）と eGFR が 低下するにつれ COVID-19関連死亡リスクが上昇し た。高度腎機能障害は従来指摘されてきたリスクで ある糖尿病（aHR 1.95）, 心疾患（aHR 1.17）, 高血 圧 (aHR 0.89) と同等もしくはより強力にCOVID-19 関連死亡に影響を与えることが示された。本邦では 透析患者の致死率が $16.7 \%$ と報告されており（2021 年 8 月 13 日時点 $)^{2)}$, 日本全体の $1.6 \%$ (2021 年 7 月 7 日時点 $)^{3)}$ と比較すると特筆すべき致死率の高さで ある. 透析患者は高齢者が多く, 年齢は最も重要な COVID-19 重症化リスクであるが，年齢で層別して も 70 歳代で $20.8 \%, 80$ 歳代で $32 \%$ と透析患者の致 死率は日本全体と比べて明らかに高く, この傾向は 欧州 (ERACODA database $)^{4)}$ からの報告とも一致し ている（表 1).

\section{COVID-19 に伴う腎障害}

\section{1）COVID-19 と急性腎障害（尿細管間質障害）}

COVID-19 に伴う急性腎障害 (acute kidney injury: AKI）は病理学的検討や低分子蛋白を多く認めるこ となどから尿細管障害が主体と考えられており ${ }^{5-8)}$, 尿細管障害の原因として COVID-19 に伴う炎症や, 循環動態悪化, 凝固異常などの影響が想定されてい る(図 1 $)^{9)}$. SARS-CoV-2 は肺胞上皮 2 型細胞の angiotensin-converting enzyme 2(ACE2) を介して感 染を起こすが, 腎臓内では近位尿細管に ACE2 発現 が豊富であり ${ }^{10)}$, SARS-CoV-2 が近位尿細管細胞に 感染し障害を起こすという仮説はあるものの結論は 
表 1 日本及び欧州に㧍ける透析患者と全体の致死率（文献 2 4 4り作成）

\begin{tabular}{lccccc}
\hline & \multicolumn{3}{c}{ 日本 } & & \multicolumn{2}{c}{ 欧州 } \\
\cline { 2 - 3 } \cline { 5 - 6 } \cline { 5 - 6 } & 透析患者 $(\%)$ & 全体 $(\%)$ & & 透析患者 $(\%)$ & 全体 $(\%)$ \\
\hline 全体 & 16.7 & 1.6 & & 25.6 & 11.4 \\
年齢（歳） & & & & & \\
$30 \sim 40$ & 0.0 & 0.0 & & 9.1 & 0.3 \\
$40 \sim 50$ & 5.8 & 0.1 & & 6.5 & 1.1 \\
$50 \sim 60$ & 6.8 & 0.3 & & 16.8 & 2.8 \\
$60 \sim 70$ & 12.1 & 1.4 & & 18.8 & 9.4 \\
$70 \sim 80$ & 20.8 & 5.1 & & 34.8 & 21.8 \\
$80 \sim$ & 32.0 & 14.2 & & 39.5 & 29.0 \\
\hline
\end{tabular}

日本のデー夕は透析患者が 2021 年 8 月 13 日時点, 全体が 2021 年 7 月 7 日時点のもの. 欧 州のデータはスペイン, オランダ, ルーマニア, イタリア, スイス, トルコ, ベルギー, イギリス, ポルトガル, ポーランドからの報告を統合したもので, 透析患者は 2020 年 2 月 から 5 月, 全体は 2020 年 6 月 8 日時点のもの.

でていない ${ }^{11)}$. メ夕解析では COVID-19で入院した 患者の $28 \%$, 重症患者の 46\%にAKIを合併したと 報告されているが ${ }^{12)}$, 採用された研究間のばらつき が極めて大きく $\left(\mathrm{I}^{2}>85 \%\right), \mathrm{AKI}$ が経時的に減少 しているという報告もある ${ }^{13,14)}$. AKI 合併率の違い はパンデミックの状況や, 医療体制, 人種の違いな どが影響している可能性があるが, COVID-19の標 準的治療法となったデキサメサゾン投与で AKIが減 少することを示唆する報告もあり ${ }^{15)}$, 今後治療の進 歩に伴いAKI 合併率が変化する可能性がある.

\section{2) COVID-19 と COVID-19関連腎症（系球体障害）}

上述の通り通常の COVID-19 に伴う AKI は尿細管 間質障害が主体で, 尿蛋白は多くなく, 重症度に応 じて発症率が増加する。しかしそれほど重症度の高 くない症例に, ネフローゼレベルの尿蛋白及び腎障 害を示す症例が複数報告されている ${ }^{8,16-19)}$ 。 それら の患者の腎組織所見では, ポドサイト傷害に起因す ると考えられる巣状分節性系球体硬化症の亜型であ る collapsing variant (collapsing glomerulopathy: $\mathrm{CG}$ ) を認めることが多い ${ }^{17-19)}$. CG は HIV 関連腎症の組 織所見として知られおり, アフリカ系アメリカ人の 腎機能障害に関連する遺伝子として同定された apolipoprotein L1（APOL1）リスクバリアントを持つ
者に, HIV 感染をセカンドヒットとして発症すると 考えられている. SARS-CoV-2 感染に伴う CG を示す 症例もやはり APOL1リスクバリアントを持つと報 告されており,この病態はCOVID-19関連腎症 (COVID-19 associated nephropathy: COVAN) とも呼 ばれている(図 1 $)^{17-20)}$. その他にも少数ながら糸球 体病変として血栓性微小血管障害や血管炎などが報 告されており ${ }^{20)}$, 最終的な腎障害の鑑別診断には腎 生検が不可欠である。

\section{COVID-19 と RAS 阻害薬}

アンジオテンシン変換酵素（ACE）阻害薬／アン ジオテンシン II 受容体拮抗薬などの RAS 阻害薬は, $\mathrm{ACE} 2$ の発現を上昇させ SARS-CoV-2 の重症化を招 くという仮説がある ${ }^{21)}$. しかし大規模な観察研究に おいて RAS 阻害薬使用と COVID-19 重症度との関連 示されず 22)，メ夕解析では RAS 阻害薬使用がむし ろ保護的に作用するとの報告されている ${ }^{23)}$. 最近 COVID-19 患者を, RAS 阻害薬中止群もしくは継続 群に割り付けたランダム化比較試験がいくつか報告 され，いずれも RAS 阻害薬中止による予後改善効果 は認められないとの結論であった ${ }^{24-26)}$. 現在は RAS 


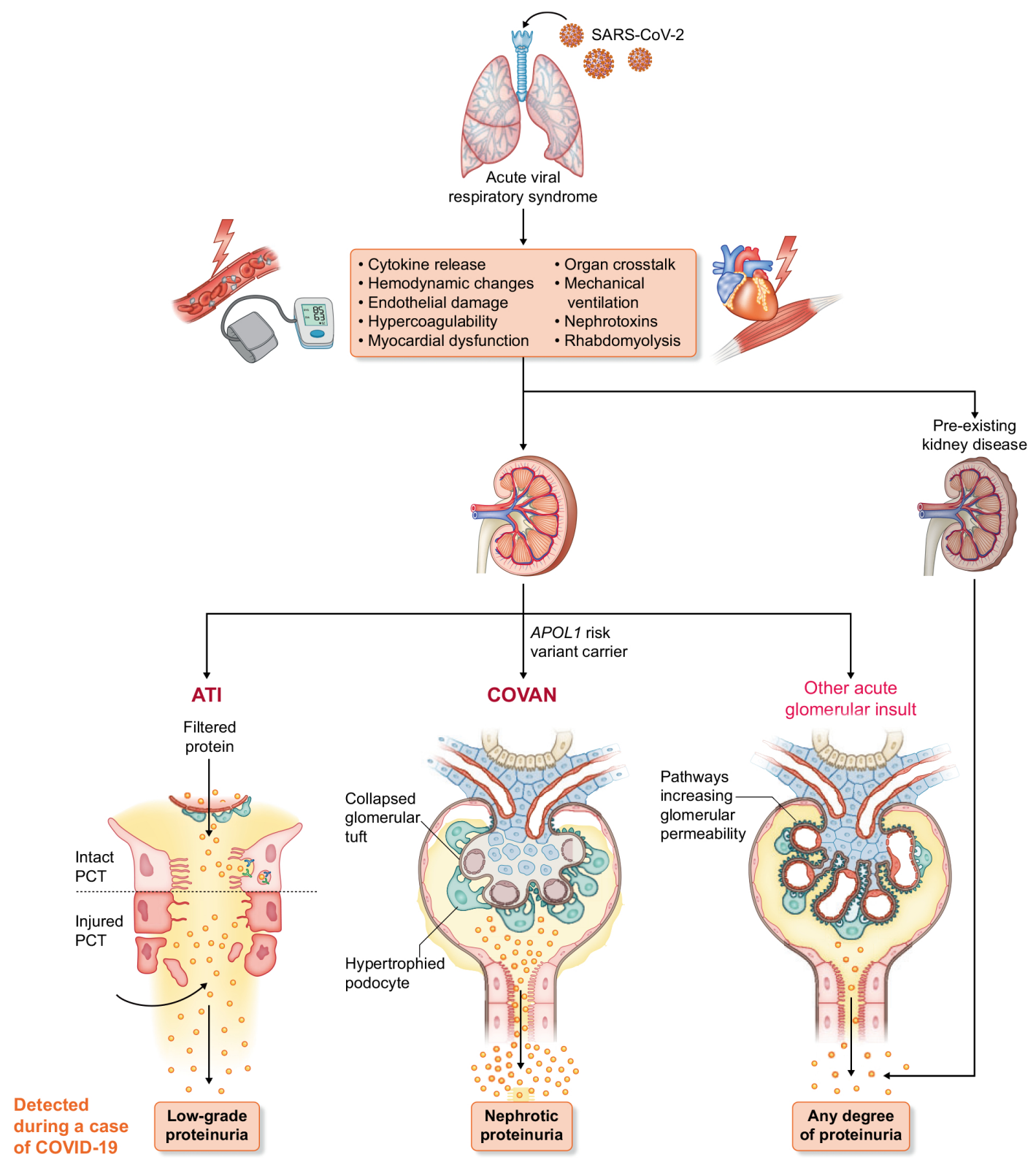

困 1 COVID-19患者に想定される腎障害（文献 9 より引用）

ATI (acute tubular injury：急性尿細管障害), COVAN (COVID-19-associated nephropathy：COVID-19 関連腎症).

阻害薬の保護的効果を期待し，COVID-19 に対して 新規にRAS 阻害薬を開始するランダム化比較試験が 複数進行中である ${ }^{27-30)}$ 。これらの研究結果発表が待 たれるが, 現在のところ特に中止する理由がない限 り COVID-19 発症後も RAS 阻害薬を継続すべきと考 えられる。

\section{5. さいごに}

本稿では COVID-19 と腎臓病の接点及び RAS 阻害 薬の話題について紹介した. CKD 患者を COVID-19 から守る方法としてワクチン接種が考えらえるが, CKD 患者においては液性免疫反応が低下しており, mRNA ワクチンの場合 3 回接種する必要があるかも しれない ${ }^{31,32)}$ 。また因果関係は証明できないものの 
COVID-19 ワクチン接種後に腎疾患の発症, 再燃が 多数報告されており新たなトピックである ${ }^{33-35)}$. 本 稿執筆中（2021 年 8 月）COVID-19 は本邦でも増加 の一途をたどっており, 適切な予防また発症後は適 切な全身管理が望まれる。

\section{著者全員の利益相反（COI）の開示：}

猪阪善隆: 講演料・原稿料など (キッセイ薬品工業, 協和キリン, 中外製薬, 田辺三菱製薬), 臨床研究 (治験)（キッセイ薬品工業, 全薬工業)

土井洋平 : 本論文発表内容に関連して開示すべき企 業等との利益相反なし

\section{文献}

1) Williamson EJ, Walker AJ, Bhaskaran K, et al.: Factors associated with COVID-19-related death using OpenSAFELY. Nature 584: 430-436, 2020.

2) 透析患者における累計の新型コロナウイルス感染者の登 録数. https://www.jsdt.or.jp/info/3325.html（2021 年 8 月 19 日確認)

3) 厚生労働省：新型コロナウイルス感染症の国内発生動向 (速報值). https://www.mhlw.go.jp/content/10906000/000813 216.pdf (2021/8/19 確認)

4) Hilbrands LB, Duivenvoorden R, Vart P, et al.: COVID-19related mortality in kidney transplant and dialysis patients: Results of the ERACODA collaboration. Nephrol Dial Transplant 35: 1973-1983, 2020.

5) Su H, Yang M, Wan C, et al.: Renal histopathological analysis of 26 postmortem findings of patients with COVID-19 in China. Kidney Int 98: 219-227, 2020.

6) Santoriello D, Khairallah P, Bomback AS, et al.: Postmortem kidney pathology findings in patients with COVID-19. J Am Soc Nephrol 31: 2158-2167, 2020.

7) Werion A, Belkhir L, Perrot M, et al.: SARS-CoV-2 causes a specific dysfunction of the kidney proximal tubule. Kidney Int 98: 1296-1307, 2020.

8) Ferlicot S, Jamme M, Gaillard F, et al.: The spectrum of kidney biopsies in hospitalized patients with COVID-19, acute kidney injury, and/or proteinuria. Nephrol Dial Transplant online ahead of print, 2021.

9) Mohamed MMB, Velez JCQ: Proteinuria in COVID-19. Clin Kid J 14: i40-i47, 2021.

10) Ye M, Wysocki J, William J, et al.: Glomerular localization and expression of Angiotensin-converting enzyme 2 and Angiotensin-converting enzyme: Implications for albuminuria in diabetes. J Am Soc Nephrol 17: 3067-3075, 2006.

11) Hassler L, Reyes F, Sparks M, et al.: Evidence for and against direct kidney infection by SARS-CoV-2 in patients with COVID-19. Clin J Am Soc Nephrol online ahead of print, 2021.

12) Silver SA, Beaubien-Souligny W, Shah PS, et al.: The prevalence of acute kidney injury in patients hospitalized with COVID-19 infection: A systematic review and meta-analysis.
Kidney Med 3: 83-98. e81, 2021.

13) Bowe B, Cai M, Xie Y, et al.: Acute kidney injury in a national cohort of hospitalized US veterans with COVID-19. Clin J Am Soc Nephrol 16: 14-25, 2020.

14) Charytan DM, Parnia S, Khatri $M$, et al.: Decreasing incidence of acute kidney injury in patients with COVID-19 critical illness in New York City. Kidney Int Rep 6: 916-927, 2021.

15) Orieux A, Khan P, Prevel R, et al.: Impact of dexamethasone use to prevent from severe COVID-19-induced acute kidney injury. Critical care (London, England) 25: 249, 2021.

16) Legrand M, Bell S, Forni L, et al.: Pathophysiology of COVID-19-associated acute kidney injury. Nat Rev Nephrol 5: 1-14, 2021.

17) Shetty AA, Tawhari I, Safar-Boueri L, et al.: COVID-19associated glomerular disease. J Am Soc Nephrol 32: 33-40, 2021.

18) Larsen CP, Bourne TD, Wilson JD, et al.: Collapsing glomerulopathy in a patient with COVID-19. Kidney Int Rep 5: 935-939, 2020.

19) Kissling S, Rotman S, Gerber C, et al.: Collapsing glomerulopathy in a COVID-19 patient. Kidney international 98: 228-231, 2020.

20) Sharma P, Ng JH, Bijol V, et al.: Pathology of COVID-19associated acute kidney injury. Clin Kid J 14: i30-i39, 2021.

21) Cüre E, Cumhur Cüre $M$ : Comment on 'Can angiotensin receptor-blocking drugs perhaps be harmful in the COVID-19 pandemic?'. J Hypertens 38: 1189-1198, 2020.

22) Mancia G, Rea F, Ludergnani $M$, et al.: Renin-angiotensinaldosterone system blockers and the risk of Covid-19. N Eng1 J Med 382: 2431-2440, 2020.

23) Baral R, Tsampasian V, Debski M, et al.: Association between renin-angiotensin-aldosterone system inhibitors and clinical outcomes in patients with COVID-19: A systematic review and meta-analysis. JAMA Netw Open 4: e213594, 2021.

24) Cohen JB, Hanff TC, William P, et al.: Continuation versus discontinuation of renin-angiotensin system inhibitors in patients admitted to hospital with COVID-19: A prospective, randomised, open-label trial. Lancet Respir Med 9: 275-284, 2021.

25) Bauer A, Schreinlechner M, Sappler N, et al.: Discontinuation versus continuation of renin-angiotensin-system inhibitors in COVID-19 (ACEI-COVID): A prospective, parallel group, randomised, controlled, open-label trial. Lancet Respir Med 9: 863-872, 2021.

26) Lopes RD, Macedo AVS, de Barros ESPGM, et al.: Effect of discontinuing vs continuing angiotensin-converting enzyme inhibitors and angiotensin II receptor blockers on days alive and out of the hospital in patients admitted with COVID-19: A randomized clinical trial. JAMA 325: 254-264, 2021.

27) Angiotensin Converting Enzyme Inhibitors in Treatment of Covid 19-Full Text View-ClinicalTrials. gov. https:// clinicaltrials.gov/ct2/show/NCT04345406（2021 年 8 月 19 日 確認)

28) Valsartan for Prevention of Acute Respiratory Distress Syndrome in Hospitalized Patients With SARS-COV-2 (COVID-19) Infection Disease - Full Text View ClinicalTrials. gov. https://clinicaltrials.gov/ct2/show/NCT043 35786 (2021 年確認) 
29) Losartan for Patients With COVID-19 Requiring Hospitalization-Full Text View-ClinicalTrials. gov. https:// clinicaltrials.gov/ct2/show/NCT04312009（2021 年 8 月 19 日 確認)

30) Efficacy of Captopril in Covid-19 Patients With Severe Acute Respiratory Syndrome (SARS) CoV-2 Pneumonia (CAPTOCOVID) - Full Text View - ClinicalTrials. gov. https://clinicaltrials.gov/ct2/show/NCT04355429（2021 年 8 月 19 日確認)

31) Danthu C, Hantz S, Dahlem A, et al.: Humoral response after SARS-CoV-2 mRNA vaccination in a cohort of hemodialysis patients and kidney transplant recipients. J Am Soc Nephrol 32: 2153-2158, 2021.
32) Ducloux D, Colladant M, Chabannes $M$, et al.: Humoral response after 3 doses of the BNT162b2 mRNA COVID-19 vaccine in patients on hemodialysis. Kidney Int 100: 702-704, 2021.

33) Plasse R, Nee R, Gao S, et al.: Acute kidney injury with gross hematuria and IgA nephropathy after COVID-19 vaccination. Kidney Int 100: 944-945, 2021.

34) Tuschen K, Bräsen JH, Schmitz J, et al.: Relapse of class V lupus nephritis after vaccination with COVID-19 mRNA vaccine. Kidney Int 100: 941-944, 2021.

35) Da Y, Goh GH, Khatri P: A case of membranous nephropathy following Pfizer-BioNTech mRNA vaccination against COVID-19. Kidney Int 100: 938-939, 2021. 